\title{
The genetics and neuroscience of flavour
}

\author{
Richard D Newcomb ${ }^{1,2^{*}}$ and Kathrin Ohla ${ }^{3^{*}}$
}

\section{Editorial}

Not only do eating and drinking provide the energy and nutrients we require to sustain life; they are also a great source of pleasure. The consumption of food is typically a multimodal experience, with the term flavour used to describe the holistic sensory experience we have during eating. At its most basic, it captures the joint sensations of taste and olfaction. However, in a wider sense, flavour covers all sensory experiences related to food intake, both chemical (such as smell, taste, chemical irritation and pain) and nonchemical (for example, the temperature, mouth feel, the visual appearance of the food and the sounds it makes when we eat it). Despite decades of research in these areas, we are only just beginning to understand the mechanisms that underlie these senses and the integration of their signals. Perhaps one of the first lessons learnt is that complex interactions between the senses are at play, with flavour not simply being the sum of its sensorial parts.

Two disciplines and associated sets of technologies are now making significant contributions to flavour research. Neuroscience, with its new noninvasive methods of investigating responses and interactions in the brain, is being bought to bear on questions of sensory integration and hedonics. In addition, genetics, with the availability of many human genome sequences and rapid methods for assessing genetic variation and identifying genes involved in sensory perception, can now contribute to questions of mechanism and differences among individuals in flavour experience.

This special issue covers neural processing and the genetic foundations of flavour perception. We welcome contributions, original research papers and integrative reviews and papers describing innovative research methods, from systems and cognitive neuroscience,

\footnotetext{
* Correspondence: Richard.Newcomb@plantandfood.co.nz; Kathrin.Ohla@dife. de

${ }^{1}$ The New Zealand Institute for Plant \& Food Research Limited, Auckland, New Zealand

${ }^{2}$ School of Biological Sciences, University of Auckland, Auckland, New Zealand
}

Full list of author information is available at the end of the article neurobiology, genetics, medicine, psychology and related disciplines.

\section{Competing interests \\ Both authors declare that they have no competing interests.}

\section{Author details}

${ }^{1}$ The New Zealand Institute for Plant \& Food Research Limited, Auckland, New Zealand. ${ }^{2}$ School of Biological Sciences, University of Auckland, Auckland, New Zealand. ${ }^{3}$ German Institute of Human Nutrition PotsdamRehbrücke, Nuthetal, Germany.

Received: 19 April 2013 Accepted: 19 April 2013

Published: 1 May 2013

\section{Submit your next manuscript to BioMed Central and take full advantage of:}

- Convenient online submission

- Thorough peer review

- No space constraints or color figure charges

- Immediate publication on acceptance

- Inclusion in PubMed, CAS, Scopus and Google Scholar

- Research which is freely available for redistribution

Submit your manuscript at www.biomedcentral.com/submit
() Biomed Central

\section{() Biomed Central}

